\title{
Efektivitas Penggunaan Mesin Panen (Combine harvester) Pada Pemanenan Padi di Kabupaten Bojonegoro
}

\section{The Effectiveness of Using Harvesting Machines (Combine Harvester) in Rice Harvesting in Bojonegoro Regency}

\author{
Badiatud Durroh ${ }^{1)}$ \\ ${ }^{1)}$ Dosen Fakultas Pertanian Universitas Bojonegoro, Indonesia \\ Email: ijolumut0@gmail.com
}

\begin{abstract}
How to Cite :
Badiatud Durroh (2020). The Effectiveness of Using Harvesting Machines (Combine Harvester) in Rice Harvesting in Bojonegoro Regency. Sinta Journal ,1 (1), 07-11. DOI: https://doi.org/13.11114/sinta.1.x.x1-x2
\end{abstract}

\section{ARTICLE HISTORY}

Received [2020-02-28]

Revised [2020-04-20]

Accepted [2020-07-15]

\section{KEYWORDS}

Effectiveness,

Harvesting, Rice,

Farmers

This is an open access article under the $C C-B Y$-SA license

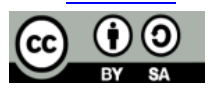

\section{ABSTRAK}

Pemanenan padi di Indonesia saat ini masih di dominasi oleh tenaga manusia dengan menggunakan tenaga kerja yang sangat tinggi, kurang lebih $40 \%$ dari penggunaaan tenaga kerja orang untuk padi sawah secara intensif. Disamping masalah tenaga kerja masalah budaya juga disebabkan tingginya susut panen padi disawah, dimana angka susut pascapanen adalah 20\%. Penelitian dilakukan di kabupaten Bojonegoro tahun 2019, ynang diwakili oleh beberapa wilayah sebagai sampel, yang dipilih dengan cara Cluster Sampling berdasarkan kecamatan. Penelitian ini menggunakan perpaduan Metode Survey Analitis dan Metode Survey Deskriptif. Hasil Penelitian menunjukkan bahwa efektifitas penggunaan mesin pemanen padi tertinggi di Kabupaten Bojonegoro adalah sebesar 58\% . Berdasarkan rasio efektivitas produksi terhadap efektivitas penggunaan mesin pemanen padi combine berada pada persentase di atas $100 \%$ dan dikategorikan Kurang efektif. Hal ini karena kinerja dari alat Combine harvester sangat dipengaruhi oleh kondisi lahan pada saat pemanenan, yang dimana pada saat panen kondisi lahan yang tergenangi air sangat berpangruh pada pergerakan alat pada lahan serta kecepatan alat pada saat panen dikarenakan kondisi tanah yang berlumpur dapat membuat kecepatan dan pergerakan alat relatif lambat. Dampak penggunaan teknologi combine terhadap pendapatan masyarakat di Kabupaten Bojojnegoro sebesar 14.600 .000 rupiah/ha (36,04\%) dengan kriteria $R / C>1$, maka usahatani mengalami keuntungan karena 
e-ISSN : -

penerimaan lebih besar dari pada pengeluaran.

Diharapkan pemerintah terus mengupayakan

pemerataan mesin pemanen padi combine harvester

karena teknologi tersebut dapat meningkatkan

pendapatan masyarakat petani.

\section{ABSTRACT}

Rice harvesting in Indonesia is currently still dominated by human labor using a very high workforce, approximately $40 \%$ of the use of labor for intensive rice. Besides labor problems, cultural problems are also caused by the high loss of rice harvest in the paddy fields, where the postharvest shrinkage rate is $20 \%$. The study was conducted in Bojonegoro district in 2019, which was represented by several regions as samples, which were selected by cluster sampling based on sub-districts. This research uses a combination of Analytical Survey Method and Descriptive Survey Method. The results showed that the effectiveness of using the highest rice harvester in Bojonegoro Regency was $58 \%$. Based on the ratio of the effectiveness of production to the effectiveness of using a combine rice harvester, the percentage is above 100\% and is categorized as less effective. This is because the performance of the Combine Harvester tool is greatly influenced by the condition of the land at harvest, which at harvest time conditions of waterlogged land greatly affect the movement of tools on the land and the speed of the tool at harvest due to muddy soil conditions can make the speed and movement relatively slow tool. The impact of the use of combining technology on community income in Bojojnegoro Regency was 14,600,000 rupiah / ha (36.04\%) with $R$ / C criteria> 1, then the farming experienced benefits because the revenue was greater than the expenditure. It is hoped that the government will continue to strive for the equalization of rice harvester combine harvester machines because this technology can increase the income of farmers.

\section{PENDAHULUAN}

Produktivitas tanaman padi semakin menurun akibat dari selain produksi padi tersendiri yang menjadi pembatas, keterbatasan tenaga kerja yaitu buruh tani yang saat sekarang banyak di dominasi umur 50 tahun keatas. Sedangkan generasi muda tidak mau menjadi buruh tani karena dianggap tidak menjajnjikan untuk menopang kehidupannya, sehingga banyak tenaga kerja pindah dari sektor pertanian ke sektor bangunan (Soegiharto dan Saraswati, 2014). 
Pemanenan padi di Indonesia saat ini masih di dominasi oleh tenaga manusia dengan menggunakan tenaga kerja yang sangat tinggi, kurang lebih $40 \%$ dari penggunaaan tenaga kerja orang untuk padi sawah secara intensif. Disamping masalah tenaga kerja masalah budaya juga disebabkan tingginya susut panen padi disawah, dimana angka susut pascapanen adalah 20\% (Handaka, 2007). Dengan kelangkaan tenaga kerja manusia, maka kacenderungan untuk menggunakan mesin mekanis semakin meningkat.Hal ini juga seiring semakin besarnya tuntutan untuk mengurangi susut pasca panen. Namun demikian, sistem pemanenan padi secara mekanis pada lahan sawah di beberapa wilayah di indonesia perlu mempertimbangkan kondisi lahan, lebih khusus lagi pada daya sangga lahan untuk menumpu mesin- mesin pemanen tersebut..Setyono (2010) menyatakan masalah utama dalam penanganan pascapanen padi adalah tingginya kehilangan hasil serta gabah dan beras yang dihasilkan bermutu rendah. Hal tersebut terjadi pada tahapan pemanenan, perontokan dan pengeringan. Masalah utama yang dihadapi dalam penanganan pascapanen padi adalah tingginya susut (losses) baik secara kuantitatif maupun kualitatif.

Permasalahan tersebut berakibat adanya kecenderungan tidak memberikan insentif kepada petani untuk memperbaiki tingkat pendapatannya (Hasbi 2012). Maka dari itu perlu adanya mesin pemanenan padi (combine harverter) yang ergonomis dengan inovasi atau pengembangan yang harus mendukung, yaitu pada bagian pemisah antara padi dan potongan daun.Dan tenaga kerja dibutuhkan hanya 3-5 orang tenaga kerja, serta luas area perhari bisa mencapai 3-4 hektar perhari. Padi merupakan salah satu komoditas tanaman pangan yang paling banyak diusahakan sebagai sumber pangan utama di Indonesia.Upaya peningkatan terhadap produksi padi terus dilakukan untuk memenuhi kebutuhan pangan masyarakat dalam rangka mendukung ketahanan pangan nasional.Perbaikan teknologi budidaya telah terbukti mampu meningkatkan produksi padi secara nyata. Pada dasarnya proses panen padi dapat dilakukan melalui dua macam cara, yaitu melalui cara tradisional dan menggunakan mesin perontok padi tipe stasioner. Mengingat adanya beberapa jenis lahan, maka kedua cara tersebut dirasa belum maksimal, sehingga perlu dilakukan perancangan dan pengembangan produk mesin pemanen padi (combine) portable. Mesin pemanen padi ini mempunyai kemampuan kerja merontokkan bulir padi dari batangnya dan sekaligus dapat menebang batang padi tersebut. Biasanya untuk satu hektar tanah, jika dilakukan dengan sistem tradisional akan memakan waktu selama empat hari. Namun dengan menggunakan teknologi pemanen padi hanya memakan waktu satu hari dan dapat menghemat biaya oprasional hingga lima puluh persen. Penelitian ini bertujuan untuk untuk melihat apakah penggunaan mesin pemanen padi di Kabupaten Bojonegoro sudah efektif dan dampak penggunaan teknologi combine terhadap pendapatan petani di kabupaten Bojonegoro.

\section{METODE PENELITIAN}

Penelitian dilakukan di kabupaten Bojonegoro tahun 2019, ynang diwakili oleh beberapa wilayah sebagai sampel, yang dipilih dengan cara Cluster Sampling berdasarkan kecamatan. Sampel kecamatan yang akan diamati berjumlah 2 kecamatan, dimana angka 2 tersebut merupakan 10\% dari total kecamatan di Kabupaten Bojonegoro yang berjumlah 28 kecamatan. Penentuan kecamatan dilakukan secara purposive berdasarkan kecamatan yang panennya bertepatan dengan pelaksanaan penelitian.

Objek penelitian terfokus kepada petani yang memanen padi secara teknologi dan pada petani pemanenan manual, sedangkan ruang lingkup penelitian terbatas 
pada efektivitas proses pemakaian teknologi combine harvester untuk memanen padi yang meliputi tepat guna serta pemanfaatan teknologi sudah efektif atau tidak efektif.

Penelitian ini menggunakan perpaduan Metode Survey Analitis dan Metode Survey Deskriptif. Metode survey analitis merupakan metode investigasi dalam pengumpulan data, dimana data yang dikumpulkan merupakan data kuantitatif yang membutuhkan analisis statistik (Yunus, H.S., 2010), Teknik pengumpulan data dalam penelitian ini menggunakan metode observasi dengan semi partisipasi, yaitu metode observasi dimana peneliti melibatkan diri dalam beberapa kegiatan masyarakat yang diamati secara tidak penuh karena terbatasnya waktu peneliti (Yunus, H.S., 2010).

Jenis data yang digunakan dalam penelitian ini adalah data primer, yang dikumpulkan melalui observasi langsung terhadap penggunaan mesin combine pada pemanenan padi. Selain itu data juga diperoleh melalui wawancara dengan daftar pertanyaan terbuka kepada pemilik lahan, pekerja perontok gabah, dan tengkulak. Populasi dalam penelitian ini adalah petani yang menggunakan teknologi combine pendapatan petani yang menggunakan teknologi combine di Kabupaten Bojonegoro.

Metode analisis yang digunakan adalah metode analisis deskriptif kuantitatif dan kualitatif. Analisis deskriptif kuantitatif digunakan untuk mengetahui efektifitas produksi dan dampak penggunaan mesin pemanen padi combine. Analisis deskriptif kualitatif digunakan untuk menjelaskan hasil yang diperoleh dari analisis kuantitatif.

\section{HASIL DAN PEMBAHASAN}

Berdasarkan hasil penelitian, menunjukkan bahwa pemanenan pada beberapa lahan persawahan didapatkan luasan lahan dan waktu panen yang ditempuh alat dalam setiap luasan lahan, dapat terlihat kapasitas lapang efektif,kapasitas lapang teoritis,efesiensi lapang serta kapasitas panen pada beberapa lahan. Dimana nilai yang didapat pada kapasitas lapang efektif tertinggi pada lahan 4 dengan luasan 2.406 m 2 dengan waktu pemanenan yang relatif lebih cepat dibandingkan dengan pemanenan pada lahan yang lain, hal ini juga dapat terlihat dari efesiensi lapang serta kapasitas panen yang terjadi pada lahan 3 dimana didapatkan efektifitas tertinggi 58 \% pada lahan 3. dari alat Combine harvester sangat dipengaruhi oleh kondisi lahan pada saat pemanenan, yang dimana pada saat panen kondisi lahan yang tergenangi air sangat berpangruh pada pergerakan alat pada lahan serta kecepatan alat pada saat panen dikarenakan kondisi tanah yang berlumpur dapat membuat kecepatan dan pergerakan alat relatif lambat.

\section{Dampak penggunaan mesin combine terhadap pendapatan petani}

Dampak penggunaan teknologi combine terhadap pendapatan masyarakat di Kabupaten Pidie Jaya dapat diketahui dari total penerimaan petani yang lebih besar dari pengeluaran atau Return Cost Ratio $(\mathrm{R} / \mathrm{C})$. Adapun rumus yang digunakan untuk menghitung $\mathrm{R} / \mathrm{C}$ adalah sebagai berikut: $\mathrm{R} / \mathrm{C}=$ Total Penerimaan Total Biaya $\mathrm{R} / \mathrm{C}=$ 4.500.000 1.800.000 R/C= 2.5 Berdasarkan perhitungan $R / C$ didapatkan nilai $R / C$ adalah 2.5. Berdasarkan kriteria pengambilan keputusan jika $R / C>1$, maka usahatani mengalami keuntungan karena penerimaan lebih besar dari pada pengeluaran.

Peningkatan pendapatan dari produksi padi yang meningkat dapat dilihat dari perbandingan produksi padi yang dihasilkan secara konvensional dan sistem teknologi combine. Produksi padi yang didapat dengan memanen secara 
konvensional adalah 7 ton/ha sedangkan hasil produksi dengan mesin pemanen dapat memberi hasil 9 ton/ha, tergantung dari baik buruknya kualitas padi.

Harga jual gabah disesuaikan dengan kualitas gabah. Pemanenan dengan combine akan menghasilkan gabah dengan kualitas bagus karena padi yang telah dipanen tidak terendap di sawah sehingga harga jual padi mencapai $4.500 \mathrm{rupiah} / \mathrm{kg}$, sedangkan pemanenan dengan sistem konvensional akan menurunkan kualitas gabah sehingga harga jualnya hanya mencapai 3.700 rupiah/kg.

Pemanenan konvensional per ha adalah:

$=$ harga jual gabah/ton $\mathrm{x}$ berat gabah

$=\operatorname{Rp} 3.700 .000 \times 7$ ton

$=\operatorname{Rp} 25.900 .000$

Pemanenan combine per ha adalah:

= harga jual gabah/ton $\mathrm{x}$ berat gabah

$=$ Rp $4.500 .000 \times 9$ ton

$=\operatorname{Rp} 40.500 .000$

Dampak pendapatan kotor

$=$ pemanenan combine - pemanenan konvensional

$=40.500 .000 \mathrm{Rp} / \mathrm{ton}-25.900 .000 \mathrm{Rp} / \mathrm{ton}$

$=14.600 .000$ rupiah/ha Atau $14.600 .000 / 40.500 .000 \times 100 \%=36,04 \%$

Peningkatan pendapatan dari pengurangan biaya operasional dapat dilihat dari perbandingan biaya yang dikeluarkan antara pemanenan sistem konvensional dengan pemanenan dengan mesin combine. Biaya yang dikeluarkan pada pemanenan dengan sistem konvensional sebesar $\mathrm{Rp}$ 2.400.000/ha, sedangkan dengan mesin combine sebesar Rp 1.800.000. terdapat selisih Rp 600.000/ha. Belum lagi biaya lain yang harus dikeluarkan karena panjangnya massa pemanenan. 


\section{KESIMPULAN}

e-ISSN : -

Efektifitas penggunaan mesin pemanen padi tertinggi di Kabupaten Bojonegoro adalah sebesar $58 \%$. Berdasarkan rasio efektivitas produksi terhadap efektivitas penggunaan mesin pemanen padi combine berada pada persentase di atas $100 \%$ dan dikategorikan Kurang efektif. Hal ini karena kinerja dari alat Combine harvester sangat dipengaruhi oleh kondisi lahan pada saat pemanenan, yang dimana pada saat panen kondisi lahan yang tergenangi air sangat berpangruh pada pergerakan alat pada lahan serta kecepatan alat pada saat panen dikarenakan kondisi tanah yang berlumpur dapat membuat kecepatan dan pergerakan alat relatif lambat.

Dampak penggunaan teknologi combine terhadap pendapatan masyarakat di Kabupaten Bojojnegoro sebesar 14.600 .000 rupiah/ha $(36,04 \%)$ dengan kriteria R/C $>1$, maka usahatani mengalami keuntungan karena penerimaan lebih besar dari pada pengeluaran. Diharapkan pemerintah terus mengupayakan pemerataan mesin pemanen padi combine harvester karena teknologi tersebut dapat meningkatkan pendapatan masyarakat petani.

\section{DAFTAR PUSTAKA}

Aulia, Wahyu. 2013. Optimalisasi Penggunaan Combine Harvester Untuk Pemanenan Padi. Departemen of Agriculture University of Syiah Kuala. Banda Aceh

BTPN . 2009. Budidaya Tanaman Padi. Balai Pengkajian Teknologi Pertanian Nangroe Aceh Darussalam.

BLP .2013. Panen dan Pasca Panen Padi. Balai Litbang Pertanian Edisi 17 - 23 Juli 2013 No.3516 Tahun XLIII.

Handaka. (2007). Sistem Kontrak Kerja \& Pilihan Mekanisasi Pascapanen Padi, . Serpong: BBP Mektan.

Hadi, Soemardi dkk. 2017. Analisis Keberlanjutan Pemanfaatan Mesin Pemanen Padi

(Combine Harvester) Di Kabupaten Lamongan Jawa Timur. Prosiding Semnas. Kendari

Hasbi. (2012). Perbaikan Teknologi Pascapanen Padi DI Lahan Suboptimal. 1(2) , 186 196.

Setyono. (2010). Perbaikan Teknologi Pasca Panen Dalam Upaya Menekan Kehilangan Hasil Padi. Pengembangan Inovasi Pertanian , 226-237.

Yunus, H. S. 2010. Metodologi Penelitian Wilayah Kontemporer. Pustaka Pelajar. Yogyakarta. 